\title{
UPAYA PENYELESAIAN WANPRESTASI DARI KREDIT USAHA RAKYAT YANG DIASURANSIKAN PADA PT ASKRINDO
}

\author{
Rani Apriani \\ Fakultas Hukum, Universitas Singaperbangsa Karawang \\ Jl. H.S. Ronggowaluyo Telukjambe Karawang 41361 \\ E-mail: rani88_fhunsika@yahoo.com
}

\begin{abstract}
Credit grant by banks should be based on the conviction of debtors capacity and capability as well as public deposit funds, because the credit provided by the bank is at risk. The government establishes Non-Collateral Loan Program called the Non-Collateral People's Business Credit (KUR). Although interference debts at KUR have been secured by PT Askrindo and PT Jamkrindo, creditors must still take into account and minimize the occurrence of bad loans. Rejection of insurance claims by PT Askrindo occur in every bank that implements KUR program for various reasons. The possible reasons for the rejection could be due to the mistake of the banks executing KUR, or from the KUR guarantor agency, which in this case is $P T$ Askrindo. Upon this incident there is contract breaching between creditors and PT Askrindo. The effort to settle the defaults of KUR insured at PT Askrindo related to the Banking Law to settle the non-performing loans can be pursued in two ways or strategies, namely credit rescue and settlement of credit.
\end{abstract}

Keywords: Insurance, Banking, KUR, PT. Askrindo.

\begin{abstract}
ABSTRAK
Pemberian kredit oleh bank harus dilandasi dengan keyakinan atas kemampuan dan kesanggupan debitor dan masyarakat penyimpanan dana, sebab kredit yang diberikan bank mengandung risiko. Pemerintah mengeluarkan program kredit tanpa jaminan yang disebut Kredit Usaha Rakyat tanpa jaminan. Walaupun kredit macet pada KUR sudah dijamin oleh PT Askrindo dan PT Jamkrindo, kreditor tetap harus memperhitungkan dan meminimalisasi terjadinya kredit macet. Penolakan klaim asuransi banyak terjadi di setiap bank yang melaksanakan program KUR dengan berbagai alasan oleh PT Askrindo. Kemungkinan alasan penolakan tersebut bisa terjadi karena kesalahan bank pelaksana KUR itu sendiri, atau dari pihak lembaga penjamin KUR, yang dalam hal ini adalah PT Askrindo. Atas kejadian ini maka terjadi wanprestasi antara kreditor dengan PT Askrindo. Upaya penyelesaian atas terjadinya Wanprestasi dari KUR yang diasuransikan pada PT Askrindo dihubungkan dengan UndangUndang Perbankan untuk menyelesaikan kredit bermasalah atau non-performing loan itu dapat ditempuh dua cara atau strategi yaitu penyelamatan kredit dan penyelesaian kredit.
\end{abstract}

Kata Kunci: Asuransi, Perbankan, KUR, PT. Askrindo.

\section{PENDAHULUAN}

Perekonomian dunia khususnya di Indonesia tidak terlepas dari peranan Usaha

Mikro Kecil dan Menengah (UMKM).

Hampir semua sektor ekonomi melibatkan peranan UMKM. Namun demikan, sangat ironis ternyata umumnya UMKM di Indonesia masih menghadapi permasalahan terutama lemah dalam pengetahuan, keterampilan, modal usaha, pemasaran, dan 
agunan, sehingga selama ini dipandang kurang memenuhi persyaratan teknis perbankan, yang pada gilirannya menjadi kendala bagi pengembangan UMKM itu sendiri. Keberhasilan Usaha Mikro, Kecil, dan Menengah (UMKM) di Indonesia tidak terlepas dari dukungan dan peran pemerintah dalam mendorong penyaluran kredit kepada UMKM.

Dalam kenyataannya, tidak semua masyarakat terutama masyarakat lapisan menengah ke bawah memiliki modal yang cukup untuk membuka atau mengembangkan usaha dan produktivitasnya. Oleh karena itu, sebagian besar mereka mengambil bantuan usaha berupa kredit untuk menjadikannya sebagai modal usaha.

Pemberian kredit tersebut dapat dilakukan secara langsung atau tidak langsung. Sebagai usaha yang penuh risiko, sebelum memberikan kredit, sebaiknya bank melakukan analisis kredit yang seksama, teliti, dan cermat dengan didasarkan pada data yang aktual dan akurat, sehingga bank tidak akan keliru dalam mengambil keputusannya. Setiap pemberian kredit tentunya telah memenuhi ketentuan perbankan dan sesuai dengan asas perkreditan yang sehat. Demikian pula pemberian kreditnya juga telah didasarkan pada penilaian yang jujur, objektif, dan terlepas dari pengaruh pihak- pihak yang berkepentingan dengan pemohon kredit. Bank harus meyakini bahwa kredit yang akan diberikannya tersebut dapat melunasi kembali pada waktunya oleh nasabah debitur dan tidak akan berkembang menjadi kredit bermasalah atau macet. ${ }^{1}$

Dalam rangka menjalankan fungsinya sebagai penyalur dana kepada masyarakat, industri perbankan memberikan kredit kepada nasabah (debitor). Pemberian kredit oleh bank pada dasarnya harus dilandasi dengan keyakinan atas kemampuan dan kesanggupan debitor dan masyarakat penyimpanan dana. Hal tersebut wajib dilaksanakan karena kredit yang diberikan bank mengandung risiko ${ }^{2}$

Dalam perkembangannya tidak semua bank telah menerapkan kredit tanpa jaminan. Beberapa tahun terakhir ini pemerintah mengeluarkan program kredit tanpa jaminan yang disebut Kredit Usaha Rakyat (selanjutnya disebut KUR) tanpa jaminan. KUR ini ditujukan dalam rangka pemberdayaan Usaha Mikro, Kecil, Menengah (UMKM), penciptaan lapangan kerja, dan penanggulangan kemiskinan.KUR ini melibatkan pemerintah, perbankan, dan lembaga penjamin. KUR tanpa jaminan dikeluarkan oleh Presiden Susilo Bambang Yudhoyono pada tanggal 5 November 2007 dengan Wujud Aplikasi Kebijakan Pemerintah

\footnotetext{
1 Usman, Rachmadi. (2001), Aspek-aspek Hukum Perbankan Indonesia, Jakarta; Gramedia Pustaka Utama. Hlm. 255.

2 Pardede, Marulak. dan Badan Pembinaan Hukum Nasional Departemen Hukum dan Hak Asasi Manusia RI. (2008), Penelitian Hukum Tentang Implementasi Jaminan Fidusia Dalam Pemberian Kredit di Indonesia. Jakarta; TP. Hlm. 1.
} 
melalui percepatan pengembangan sektor riil dan pemberdayaan Usaha Mikro, Kecil, dan Menengah yang tertuang dalam Instruksi Presiden Nomor 6 Tahun 2007 dan sebagai Landasan Operasionalnya adalah Instruksi Presiden Nomor 5 Tahun 2008 tentang Fokus Program Ekonomi Tahun 2008-2009 untuk menjamin implementasi atau percepatan pelaksanaan KUR ini.

Berbagai kemudahan bagi UMKM pun ditawarkan oleh pemerintah. Beberapa di antaranya adalah penyelesaian kredit bermasalah UMKM dan pemberian kredit UMKM hingga $\mathrm{Rp} 500$ juta. Instruksi Presiden tersebut didukung dengan Peraturan Menteri Keuangan Nomor 135/PMK.05/2008 tentang Fasilitas Penjaminan KUR. Jaminan KUR sebesar 70 persen bisa dijamin oleh pemerintah melalui PT Asuransi Kredit Indonesia (Askrindo) dan PT Jaminan Kredit Indonesia (PT Jamkrindo), sedangkan 30 persen dijamin oleh Bank Pelaksana. ${ }^{3}$ Program KUR merupakan tindak lanjut dari ditandatanganinya Nota Kesepahaman Bersama (MoU) pada tanggal 9 Oktober 2007 tentang Penjaminan Kredit/ Pembiayaan kepada UMKM dan Koperasi antara Pemerintah (Menteri Negara Koperasi dan UKM, Menteri Keuangan, Menteri Pertanian, Menteri Kehutanan, Menteri Kelautan dan Perikanan, Menteri Perindustrian, Perusahaan Penjamin
(Perum Sarana Pengembangan Usaha dan PT. Asuransi Kredit Indonesia) dan Perbankan (Bank Rakyat Indonesia, Bank Mandiri, Bank BNI, Bank BTN, Bank Bukopin, dan Bank Syariah Mandiri). KUR ini didukung oleh Kementerian Negara BUMN, Kementerian Koordinator Bidang Perekonomian serta Bank Indonesia.

KUR adalah skema kredit/pembiayaan modal kerja dan atau investasi yang khusus diperuntukkan bagi Usaha Mikro Kecil Menengah dan Koperasi (UMKMK) di bidang usaha produktif dan layak (feasible), namun mempunyai keterbatasan dalam pemenuhan persyaratan yang ditetapkan Perbankan (belum bankable). KUR merupakan program pemberian kredit/pembiayaan dengan nilai dibawah $\mathrm{Rp} 500.000 .000$ dengan pola penjaminan oleh Pemerintah dengan besarnya cakupan penjaminan maksimal $80 \%$ dari plafon kredit untuk sektor pertanian, kelautan dan perikanan, kehutanan, dan industri kecil, dan $70 \%$ dari plafon kredit untuk sektor lainnya.

Lembaga penjaminnya yang terlibat adalah dua lembaga penjamin nasional, yaitu PT Jamkrindo dan PT Askrindo, ${ }^{4}$ serta 10 Perusahaan Penjaminan Kredit Daerah (PPKD). Masih rendahnya keinginan daerah untuk mendirikan PPKD ini terbentur sejumlah persoalan. Salah satunya masalah

\footnotetext{
3 Rahma, Rani. (2017, Mei, 1), Program Kredit Usaha Rakyat, 18 April 2018, TNP2K, http://www.tnp2k.go.id/id/program/program/dprogram-kredit-usaha-rakyat-.

4 Ibid. Hlm. 5.
} 
pembentukan Peraturan Daerah (Perda) yang menjadi dasar hukum dari berdirinya PPKD, khususnya Perda mengenai penyertaan modal dari Pemda. Hingga kini baru ada 10 daerah yang mendirikan PPKD dan memperoleh izin usaha dari OJK. Pemda yang telah mendirikan PPKD tersebut adalah PT Jamkrida Jawa Timur, PT Jamkrida Nusa Tenggara Barat Bersaing, PT Jamkrida Bali Mandara, PT Jamkrida Jawa Barat, PT Jamkrida Kalimantan Selatan, PT Jamkrida Sumatera Selatan, PT Jamkrida Kalimantan Tengah, PT Jamkrida Bangka Belitung, PT Jamkrida Riau dan PT Jamkrida Sumatera Barat. Pendirian PPKD di sejumlah daerah ini bertujuan untuk membantu penjaminan bisnis Usaha Mikro Kecil dan Menengah (UMKM) di daerahdaerah tersebut. ${ }^{5}$

Walaupun kredit macet pada KUR sudah dijamin oleh PT Askrindo dan PT Jamkrindo, kreditor tetap harus memperhitungkan dan meminimalisasi terjadinya kredit macet. Hal ini dikarenakan tidak adanya jaminan yang diberikan oleh debitor kepada perbankan, sehingga jika terjadi wanprestasi, maka bank harus mengurus klaim asuransi yang prosedurnya tidak semudah teorinya. Pada kenyataannya banyak KUR yang macet dan klaim asuransinya tidak lolos di PT Askrindo dan PT Jamkrindo sebagai lembaga penjamin.

KUR yang macetpun kemungkinan berasal dari persepsi/pemahaman yang salah dari masyarakat terhadap KUR, KUR dianggap dana dari pemerintah, serta dijamin oleh pemerintah bukan merupakan kredit dari Bank. Hal ini mempengaruhi tingkat pengembalian (angsuran) dan kualitas KUR. Selain itu, adanya pemahaman/anggapan sebagian masyarakat bahwa KUR merupakan Kredit Tanpa Agunan atau bahkan bantuan/hibah. Jika terjadi wanprestasi atas KUR yang disalurkan oleh bank, dampaknya adalah kerugian yang besar, karena beberapa KUR disalurkan tanpa agunan. Sebenarnya pihak kreditor (bank) tidak perlu khawatir dengan kerugian-kerugian tersebut, karena KUR ini di-cover oleh lembaga penjamin. Namun pada kenyataannya, banyak KUR yang klaim asuransinya ditolak oleh PT Askrindo.

Penolakan klaim asuransi banyak terjadi di setiap bank yang melaksanakan program KUR dengan berbagai alasan oleh PT Askrindo. Penolakan klaim asuransi kredit oleh PT Askrindo sangat merugikan bank pelaksana KUR. Kemungkinan alasan penolakan tersebut bisa terjadi karena kesalahan bank pelaksana KUR itu sendiri, atau dari pihak lembaga penjamin KUR, yang dalam hal ini adalah PT Askrindo.Namun setiap penolakan klaim asuransi KUR berdampak pada kerugian kreditor, sehingga perlu diketahui penyebab penolakan klaim asuransi dan perlindungan hukum terhadap

Hayini, Susan. (2014, Agustus 21). Pemda Dirikan Perusahaan Penjaminan Kredit, Diakses pada April, 18, 2018, Hukum Online: http://www.hukumonline.com/berita/baca/, 
pihak kreditor tersebut. Hal ini yang menyebabkan terjadinya wanprestasi atas perjanian yang telah disepakati oleh kreditor dengan PT. Askrindo. Berdasarkan uraian diatas, maka penulis tertarik untuk mengambil judul mengenai: "UPAYA PENYELESAIAN WANPRESTASI DARI KREDIT USAHA RAKYAT YANG DIASURANSIKAN PADA PT ASKRINDO”. Adapun rumusan masalah dari judul tersebut yaitu Bagaimana Upaya Penyelesaian Atas Terjadinya Wanprestasi Dari Kredit Usaha Rakyat Yang Diasuransikan Pada PT Askrindo Dihubungkan Dengan Undang - Undang Perbankan?

Metode penelitian yang digunakan oleh penulis yaitu untuk memperoleh informasi atau data yang akurat, yang berkaitan dan relevan dengan permasalahan dan penyelesaian penulisan skripsi ini, maka dipilih lokasi penelitian yaitu Karawang dengan pihak kreditor yaitu Bank Rakyat Indonesia (BRI) Unit Lamaran. Selain pihak kreditor di atas, penulis juga melakukan penelitian pada pihak debitor yaitu pengusaha UMK (Usaha Mikro dan Kecil), serta lembaga penjamin pada Kredit Usaha Rakyat (KUR) yaitu PT Asuransi Kredit Indonesia (Askrindo) Cabang Jawa Barat. Dengan melakukan penelitian di lokasi tersebut, akan sangat memudahkan untuk mengakses data demi keakuratan penyusunan skripsi ini.

Data yang akan dikumpulkan adalah:

- Data primer, Kitab Undang-Undang Hukum Perdata (Burgelijk Wetbook);
Kitab Undang-Undang Hukum Dagang (KUHD). Undang-Undang Nomor 10 Tahun 1998 tentang PerubahanUndangUndang Nomor 7 Tahun 1992 Tentang Perbankan, Undang - Undang Nomor 40 Tahun 2014 tentang Perasuransian. Peraturan Menteri Keuangan No. 135/PMK.05/2008 tentan Fasilitas Penjamin Kredit Usaha Rakyat yang telah di ubah dengan PMK No. 10/PMK.05/2009

Data Sekunder, yang diperoleh langsung dari lapangan dengan cara melakukan wawancara kepada kreditor yang terdiri dari Bank Rakyat Indonesia (BRI), pihak debitor yaitu Para Pengusaha UMK (Usaha Mikro dan Kecil), serta lembaga penjamin pada Kredit Usaha Rakyat (KUR) yaitu PT Asuransi Kredit Indonesia (Askrindo) Unit Lamaran.

- Data tersier, yaitu literatur, peraturan perundang-undangan, dokumen berupa Surat Perjanjian Kerja Sama antara pihak bank dan PT Asuransi Kredit Indonesia (Askrindo) mengenai KUR, Surat Perjanjian Kredit antara pihak bank dengan debitor, serta data lainnya yang berkaitan dengan masalah yang dibahas dalam skripsi ini.

Teknik Pengumpulan Data Untuk memperoleh data yang dibutuhkan guna melengkapi penelitian yang dilakukan, maka penulis mempergunakan teknik pengumpulan data yang terbagi atas: 
- Wawancara, Wawancara adalah suatu teknik pengumpulan data dengan mengajukan pertanyaan langsung kepada responden, yaitu dari pihak Bank Rakyat Indonesia, pengusaha UMK (Usaha Mikro dan Kecil), serta PT Askrindo.

- Studi Pustaka Studi pustaka dalam teknik pengumpulan data ini merupakan jenis data sekunder yang digunakan unutuk membantu proses penelitian, yaitu dengan mengkaji dan menganalisis literature peraturan perundang-undangan, serta datum lainnya yang berkaitan dengan masalah yang dibahas dalam skripsi ini.

Metode yang digunakan dalam penelitian ini adalah pendekatan sosiologi hukum (Socio-Legal Approach) karena permasalahan yang diteliti ini didekati dari masyarakat selaku debitor dan kreditor, hukum, perbankan, serta asuransi kredit sedangkan spesifikasi penelitian yang digunakan berupa penelitian deskriptif yang artinya prosedur pemecahan masalah yang diteliti dengan menggambarkan objek dan subjek hukum pada saat sekarang berdasarkan fakta-fakta yang ada.

Populasi dan Sampel Populasi dalam penelitian ini meliputi lembaga perbankan sebagai kreditor, debitor KUR, serta lembaga penjamin KUR yang ada di Karawang, sedangkan sampel dalam penelitian ini ditetapkan dengan teknik sampling random yaitu dengan cara menetapkan jumlah kriteria sampel yang ditetapkan oleh peneliti dengan jumlah yang terbatas. Adapun sampel peneliti terdiri dari kreditor bank, yaitu Bank Rakyat Indonesia (BRI), pengusaha UMK (Usaha Mikro dan Kecil) selaku debitor KUR yang terdiri dari 10 orang pedagang, 5 orang pemilik warung makan, 2 orang pemilik toko kelontong, 4 orang penjual parfum, serta lembaga penjamin KUR yaitu PT Asuransi Kredit Indonesia (Askrindo) Cabang Jawa Barat.

Metode analisis data yang digunakan adalah metode kualitatif, yaitu analisis yang memadukan data berupa hasil pengamatan, wawancara, bahan tertulis berupa buku-buku terkait dengan penelitian ini, MoU antara Departemen Teknis, Perbankan, dan Perusahaan Penjaminan yang ditandatangani, serta Perjanjian Kerja Sama antara Bank Rakyat Indonesia (BRI) dengan pihak PT Asuransi Kredit Indonesia (Askrindo) mengenai KUR yang kemudian dianalisis secara deskriptif yang akan memberikan gambaran yang menyeluruh mengenai permasalahan yang diteliti, mencari pemecahan, dan menarik kesimpulan, maka dapat diperoleh suatu hasil yang menggambarkan faktor-faktor apa yang menyebabkan tidak dibayarnya klaim asuransi kredit usaha rakyat (KUR) yang diajukan oleh pihak bank kepada PT. Askrindo serta perlindungan hukum terhadap pihak bank tersebut. 


\section{PEMBAHASAN}

Upaya Penyelesaian Atas Terjadinya Wanprestasi Dari Kredit Usaha Rakyat Yang Diasuransikan Pada PT Askrindo Dihubungkan Dengan Undang - Undang Perbankan

Perkreditan merupakan salah satu usaha penting bagi bank dalam memberikan keuntungan, tetapi berbagai masalah atas penyaluran kredit harus dihadapi perbankan. Akhir-akhir ini banyak kritikan terhadap kinerja perbankan nasional yang dilakukan oleh praktisi keuangan ataupun lembagalembaga pemerintahan. Hal ini sehubungan dengan adanya kredit bermasalah yang biasa disebut Non Performance Loan (NPL) dengan jumlah yang cukup signifikan di sejumlah bank tersebut. Berita kredit bermasalah di sejumlah bank telah menimbulkan implikasi kurang baik bagi Bank itu sendiri. Beberapa debitur berkualitas bagus mulai pindah ke bank lain. Disinyalir debitur yang pindah tersebut khawatir jangan-jangan kredit mereka hanya menunggu giliran untuk diungkap di media massa oleh pemeriksa. ${ }^{6}$

Kredit bermasalah atau nonperforming loan merupakan resiko yang terkandung dalam setiap pemberian kredit oleh bank kepada nasabahnya. Resiko tersebut berupa keadaan di mana kredit tidak dapat kembali tepat pada waktunya (wanprestasi). Kredit bermasalah atau nonperforming loan di perbankan itu dapat di sebabkan oleh beberapa faktor, misalnya, ada kesengajaan dari pihak-pihak yang terlibat dalam proses kredit, kesalahan prosedur pemberian kredit, atau disebabkan faktor lain seperti faktor makro ekonomi.

Pemberian kredit yang tertuang dalam suatu perjanjian tidak dapat dilepaskan dari prinsip kepercayaan, yang sering menjadi sumber malapetaka bagi kreditur sehubungan dengan kredit macet. Berbagai unsur seperti safety, soundness, without substantial riskpun dalam perundang-undangan/peraturan perlu mendapatkan perhatian, karena dalam kenyataannya kurang memuaskan untuk menyelesaikan permasalahan kredit macet. ${ }^{7}$

Dalam peraturan Bank Indonesia Nomor 7/2/PBI/2005 disebutkan bahwa kredit dikategorikan sebagai kredit bermasalah atau non-performing loan (NPL) tersebut adalah apabila kualitas kredit tersebut tergolong pada tingkat kolektibilitas kurang lancar, diragukan, atau macet. Untuk kredit-kredit bermasalah yang bersifat non struktural, pada umumnya dapat diatasi dengan langkahlangkah restrukturisasi berupa penurunan suku bunga kredit, perpanjangan jangka waktu, pengurangan tunggakan bunga kredit, pengurangan tunggakan pokok kredit, penambahan fasilitas kredit, atau konversi kredit menjadi pernyataan sementara. Sedangkan untuk kredit-kredit bermasalah

\footnotetext{
6 Bahsan, M. (2002), Penilaian Jaminan Kredit Perbankan Indonesia, Jakarta; Rejeki Agung, Hlm.148.

7 Putra, Edy. (1989), The 'Aman, Kredit Perbankan Suatu Tinjauan Yuridis, Yogyakarta; Liberty, Hlm. 145.
} 
yang bersifat struktural pada umumnya tidak dapat diselesaikan dengan restrukturisasi sebagaimana kredit bermasalah yang bersifat nonstruktural, melainkan harus diberikan pengurangan pokok kredit (haircut) agar usahanya dapat berjalan kembali dan pendapatannya mampu untuk memenuhi kewajiban-kewajibannya. ${ }^{8}$

Untuk menyelesaikan kredit bermasalah atau non-performing loan itu dapat ditempuh dua cara atau strategi yaitu penyelamatan kredit dan penyelesaian kredit. Yang dimaksud dengan penyelamatan kredit adalah suatu langkah penyelesaian kredit bermasalah melalui perundingan kembali antara bank sebagai kreditor dan nasabah peminjam sebagai debitor, sedangkan penyelesaian kredit adalah suatu langkah penyelesaian kredit bermasalah melalui lembaga hukum. Yang dimaksud dengan lembaga hukum dalam hal ini adalah Panitia Urusan Piutang Negara (PUPN) dan Direktorat Jendral Piutang dan Lelang Negara (DJPLN), melalui Badan Peradilan, dan melalui Arbitrase atau Badan Alternatif Penyelesaian sengketa.

Penanganan kredit bermasalah sebelum diselesaikan secara yudisial dilakukan melalui penjadwalan (rescheduling), persyaratan (reconditioning), dan penataan kembali (restructuring). Penanganan dapat melalui salah satu cara ataupun gabungan dari ketiga cara tersebut. Setelah ditempuh dengan cara tersebut dan tetap tidak ada kemajuan penanganan, selanjutnya diselesaikan secara yudisial melalui jalur pengadilan, pengadilan Niaga, melalui PUPN, dan melalui Lembaga Paksa Badan.

Mengenai penyelamatan kredit bermasalah dapat dilakukan dengan berpedoman kepada Surat Edaran Bank Indonesia No. 26/4/BPPP tanggal 29 Mei 1993 yang pada prinsipnya mengatur penyelamatan kredit bermasalah sebelum diselesaikan melalui lembaga hukum adalah melalui alternatif penanganan secara penjadwalan kembali (rescheduling), persyaratan kembali (reconditioning), dan penataan kembali (restructuring). Dalam surat edaran tersebut yang dimaksud dengan penyelamatan kredit bermasalah melalui rescheduling, reconditioning, dan restructuring adalah sebagai berikut: ${ }^{9}$

1. Melalui rescheduling (penjadwalan kembali), yaitu suatu upaya hukum untuk melakukan perubahan terhadap beberapa syarat perjanjian kredit yang berkenaan dengan jadwal pembayaran kembali/ jangka waktu kredit termasuk tenggang (grace priod), termasuk perubahan jumlah angsuran. Bila perlu dengan penambahan kredit.

2. Melalui reconditioning (persyaratan kembali), yaitu melakukan perubahan

\footnotetext{
8 HS., Salim. (2004), Perkembangan Hukum Jaminan di Indonesia, RajaGrafindo Persada, Jakarta, Hlm. 168

9 Firdaus, Rachmat dan Ariyani, Maya. (2004), Manajemen Perkreditan Bank Umum, Alfabeta, Bandung. Hlm. 44-50.
} 
atas sebagian atau seluruh persyaratan perjanjian, yang tidak terbatas hanya kepada perubahan jadwal angsuran, atau jangka waktu kredit saja. Tetapi perubahan kredit tersebut tanpa memberikan tambahan kredit atau tanpa melakukan konversi atas seluruh atau sebagian dari kredit menjadi equity perusahaan.

3. Melalui restructuring (penataan kembali), yaitu upaya berupa melakukan perubahan syarat-syarat perjanjian kredit berupa pemberian tambaha kredit, atau melakukan konversi atas seluruh atau sebagian kredit menjadi perusahaan, yang dilakukan dengan atau tanpa rescheduling atau reconditioning.

Restrukturisasi Kredit adalah upaya perbaikan yang dilakukan Bank dalam kegiatan perkreditan terhadap debitur yang mengalami kesulitan untuk memenuhi kewajibannya, yang dilakukan antara lain melalui: ${ }^{10}$

a. penurunan suku bunga Kredit;

b. perpanjangan jangka waktu Kredit;

c. pengurangan tunggakan bunga Kredit;

d. pengurangan tunggakan pokok Kredit;

e. penambahan fasilitas Kredit; dan atau

f. konversi Kredit menjadi Penyertaan Modal Sementara

Sebagaimana diketahui dalam praktek penyelesaian masalah kredit macet diawali dengan upaya-upaya dari bank sebagai pihak kreditur dengan berbagai cara antara lain dengan melakukan penagihan langsung oleh bank kepada debitur yang bersangkutan atau mengupayakan agar debitur menjual agunan kreditnya sendiri untuk pelunasan kreditnya di bank. Apabila penyelesaian sebagaimana tersebut diatas tidak berhasil dilaksanakan, pada umumnya upaya yang dilakukan bank dilakukan melalui prosedur hukum. Sehubungan dengan hal tersebut, sesuai dengan peraturan perundang-undangan yang berlaku terdapat beberapa lembaga dan berbagai sarana hukum yang dapat dipergunakan untuk mempercepat penyelesaian masalah kredit macet perbankan.

Penganuh kelembagaan terhadap kelancaran penyelesaian krisis perbankan menunujukkan pengaruh yang penting. Krisis perbankan membebani fiskal terutama apabila dilaksanakan kebijakan seperti rekapitalisasi perbankan, bantuan likuiditas, dan jaminan pemerintah yang eksplisit terhadap lembagalembagakeuangan, sertapenerapan kelonggaran atas peraturan prudensial. Kelembagaan yang lebih baik yang melaksanakan pengurangan praktik korupsi dan memperbaiki hukum dan ketentuan, sistem hukum, dan birokrasi, maka akan dihasilkan teknik yang lebih berkesinambungan untuk memonitor dan mengawasi dampak lingkungan yang kurang baik dari kelembagaan dalam menghadapi

${ }^{10}$ Ibid, Hlm. 134. 
kemungkinan krisis keuangan dan besarnya biaya fiskal.

Disarankan agar negara-negara menerapkan kebijakan yang ketat dalam menyelesaikan krisis dan menggunakan krisis sebagai kesempatan untuk melaksanakan reformasi struktural jangkah menengah yang sekaligus diharapkan dapat membantu mencegah krisis sistemik yang akan datang. Adapun lembaga yang berfungsi untuk menyelesaikan masalah kredit macet perbankan dapat diuraikan pada sub bagian dibawah ini. ${ }^{11}$

1. Pengadilan Negeri

Berdasarkan Undang-Undang Dasar 1945 dan pasal 10 Undang-Undang No.14 Tahun 1970, badan peradilan merupakan lembaga yang sah dan berwenang untuk menyelesaikan sengketa. Sebagai tindak lanjut dari Undang-Undang Nomor 14 tahun 1970 ditetapkan berbagai peraturan perundangundangan yang menentukan batas yurisdiksi untuk setiap badan peradilan. Khusus berkenaan dengan permasalahan sengketa perkreditan, yurisdiksinya termasuk kewenangan lingkungan peradilan umum, sehingga badan peadilan yang secara resmi bertugas menyelesaikan kredit macet bila disengketakan adalah Pengadilan Negeri. Penyelesaian sengketa kredit macet bank- bank swasta dapat diselesaikan melalui Pengadilan Negeri dengan 2 (dua) cara:

a. Bank menggugat nasabah karena telah melakukan wanprestasi atas perjanjian kredit yang telah disepakati. Bank dapat menggugat debitur yang melakukan wanprestasi dengan tidak membayar utang pokok maupun bunga ke Pengadilan Negeri. Pengadilan Negeri dalam hal ini akan memproses gugatan tersebut dengan mempertimbangkan buktibukti dan sanggahan-sanggahan yang diajukan oleh kedua belah pihak. Apabila proses pemeriksaan selesai dilakukan, Pengadilan Negeri akan mengeluarkan putusan. Putusan tersebut dilaksanakan dengan sita eksekusi atas agunan yang diberikan untuk kepentingan pelunasan kredit.

b. Bank meminta penetapan sita eksekusi terhadap barang agunan debitur yang telah diikat secara sempurna. Terhadap barang agunan yang telah diikat secara sempurna, seperti dengan cara hipotik (sekarang Hak Tanggungan) atau credietverband, maka bank dapat langsung mengajukan permohonan penetapan sita eksekusi barang agunan untuk dapat memperoleh

\footnotetext{
${ }^{11}$ Firdaus, Rachmat. dan Ariyani, Maya. (2004) Manajemen Perkreditan Bank Umum, Bandung; Alfabeta, Hlm.
} 97. 
pelunasan piutangnya tanpa harus melalui proses gugatan biasa di Pengadilan. ${ }^{12}$

2. Panitia Urusan Piutang Negara (PUPN)

Dengan Undang-Undang No.49 Prp. Tahun 1960, Panitia Urusan Piutang Negara (PUPN) bertugas menyelesaikan piutang negara yang telah diserahkan kepadanya oleh instansi pemerintah atau badan-badan negara. Dengan demikian bagi bank milik negara penyelesaian masalah kredit macetnya harus dilakukan melalui Panitia Urusan Piutang Negara (PUPN), dimana dengan adanya penyerahan piutang macet kepada badan tersebut secara hukum wewenang penguasaan atas hak tagih dialihkan kepadanya. Pengurusan piutang negara dimaksud dilakukan dengan membuat Pernyataan Bersama antara PUPN dan debitur tentang besarnya jumlah hutang dan kesanggupan debitur untuk menyelesaikannya. Pernyataan Bersama tersebut mempunyai kekuatan pelaksanaan seperti putusan hakim dalam perkara perdata yang berkekuatan pasti, sehingga pernyataan tersebut mempunyai titel eksekutorial.

Jika debitur menolak membuat Pernyataan Bersama, maka Ketua PUPN dapat menetapkan besarnya jumlah hutang sendiri. Dalam hal Pernyataan
Bersama tidak dipenuhi oleh debitur, PUPN dapat memaksa debitur untuk membayar sejumlah hutang dengan surat paksa, sehingga selanjutnya penyitaan dan pelelangannya disamakan dengan penagihan pajak negara (pasal 11 UndanUndang Nomor 49 Prp.tahun 1960).

Dengan demikian penagihan piutang negara dilakukan sesuai dengan parate eksekusi. Surat Paksa dikeluarkan dalam bentuk keputusan Ketua PUPN dengan titel eksekutorial yang mempunyai kekuatan seperti grosse putusan hakim dalam perkara perdata yang tidak dapat diajukan banding lagi. Upaya penyelesaian yang dilakukan yaitu dengan dua cara yaitu penyelamatan kredit dan penyelesaian kredit. Yang dimaksud dengan penyelamatan kredit adalah suatu langkah penyelesaian kredit bermasalah melalui perundingan kembali antara bank sebagai kreditor dan nasabah peminjam sebagai debitor, sedangkan penyelesaian kredit adalah suatu langkah penyelesaian kredit bermasalah melalui lembaga hukum. Lembaga hukum yang dimaksud dalam hal ini adalah Panitia Urusan Piutang Negara (PUPN) dan Direktorat Jendral Piutang dan Lelang Negara (DJPLN), melalui Badan Peradilan, dan melalui Arbitrase atau Badan Alternatif Penyelesaian sengketa.

\footnotetext{
${ }^{12}$ OP. Simorangkir, (1988), Seluk Beluk Bank Komersial, Aksara Persada Indonesia, Jakarta, hal. 91.
} 


\section{KESIMPULAN}

Upaya penyelesaian atas terjadinya Wanprestasi dari KUR yang diasuransikan pada PT Askrindo dihubungkan dengan Undang-Undang Perbankan untuk menyelesaikan kredit bermasalah atau non-performing loan itu dapat ditempuh dua cara atau strategi yaitu penyelamatan kredit dan penyelesaian kredit. Yang dimaksud dengan penyelamatan kredit adalah suatu langkah penyelesaian kredit bermasalah melalui perundingan kembali antara bank sebagai kreditor dan nasabah peminjam sebagai debitor, sedangkan penyelesaian kredit adalah suatu langkah penyelesaian kredit bermasalah melalui lembaga hukum. Lembaga hukum yang dimaksud dalam hal ini adalah Panitia Urusan Piutang Negara (PUPN) dan Direktorat Jendral Piutang dan Lelang Negara (DJPLN), melalui Badan Peradilan, dan melalui Arbitrase atau Badan Alternatif Penyelesaian sengketa.

\section{SARAN}

Seharusnya pejabat bank bagian kredit dalam melaksanakan analisis sistem dan tata cara 6 C's of Credit (Character, Capacity, Capital, Collateral, Condition ofeconomy, and Competence to borrow) diharapkan melakukan analisis dengan lebih cermat dan cerdik. Hal tersebut untuk mencegah terjadinya kredit bermasalah/macet pada masa yang akan datang, karena berhasil tidaknya penyaluran kredit bank dapat mempengaruhi kredibilitas bank yang bersangkutan. Diharapkan dalam penyelesaian kredit bermasalah, terjadi kerjasama yang baik antara pihak nasabah, bank, dan pihak ketiga yang membantu penyelesaian kredit bermasalah tersebut. Karena kedua belah pihak baik itu pihak bank atau pihak nasabah akan terus terbebani dengan waktu dan biaya penyelesaian kredit bermasalah tersebut.

\section{DAFTAR PUSTAKA}

\section{Peraturan Perundang-undangan}

Kitab Undang-Undang Hukum Perdata (Burgelijk Wetbook);

Kitab Undang-Undang Hukum Dagang (KUHD)

Undang-Undang Nomor 10 Tahun 1998 tentang Perubahan Undang-Undang Nomor 7 Tahun 1992 Tentang Perbankan;

Undang - Undang Nomor 40 Tahun 2014 tentang Perasuransi

Peraturan Bank Indonesia Nomor: 7/2/PBI/2005 Tentang Penilaian Kualitas Aktiva Bank Umum

Peraturan Menteri Keuangan No. 135/PMK.05/2008 tentan Fasilitas Penjamin Kredit Usaha Rakyat yang telah di ubah dengan PMK No. 10/PMK.05/2009

\section{Buku}

Bahsan, M. (2002), Penilaian Jaminan Kredit Perbankan Indonesia, Jakarta; Rejeki Agung.

Firdaus, Rachmat dan Ariyani, Maya. (2004), Manajemen Perkreditan Bank Umum, Alfabeta, Bandung.

HS., Salim. (2004), Perkembangan Hukum Jaminan di Indonesia, RajaGrafindo Persada, Jakarta. 
OP. Simorangkir, (1988), Seluk Beluk Bank Komersial, Jakarta: Aksara Persada Indonesia.

Pardede, Marulak. dan Badan Pembinaan Hukum Nasional Departemen Hukum dan Hak Asasi Manusia RI. (2008), Penelitian Hukum Tentang Implementasi Jaminan Fidusia Dalam Pemberian Kredit di Indonesia. Jakarta; TP.

Putra, Edy. (1989), The 'Aman, Kredit Perbankan Suatu Tinjauan Yuridis, Yogyakarta; Liberty.

Usman, Rachmadi. (2001), Aspek-aspek Hukum Perbankan Indonesia, Jakarta; Gramedia Pustaka Utama.

\section{Internet}

Rahma, Rani. (2017, Mei, 1), Program Kredit Usaha Rakyat, 18 April 2018, TNP2K, http://www.tnp2k.go.id/id/program/pro gram/dprogram-kredit-usaha-rakyat-.

Hayini, Susan. (2014, Agustus 21). Pemda Dirikan Perusahaan Penjaminan Kredit, Diakses pada April, 18, 2018, Hukum Online: http://www.hukumonline.com/berita/ba $\mathrm{cal}$, 